Rev. Int. Contam. Ambie. 36 (1) 139-149, 2020

DOI: $10.20937 /$ RICA.2020.36.53492

\title{
INDUSTRIES AND ENVIRONMENTAL IMPACT ASSESSMENT: ANALYSIS OF THE SCREENING PROCESS IN ARGENTINA
}

Industrias y evaluación de impacto ambiental: análisis del proceso de revisión inicial en Argentina

\author{
Agustina BARILARI*, Héctor Enrique MASSONE, María Lourdes LIMA and Cecilia Lucía MANTECÓN
}

Instituto de Geología de Costas y del Cuaternario, Universidad Nacional de Mar del Plata - Comisión de Investigaciones Científicas, Provincia de Buenos Aires. Funes 3350, Mar del Plata, CP 7600, Buenos Aires, Argentina *Corresponding auhor: agustinabarilari@gmail.com

(Received: December 2018; accepted: May 2019)

Key words: environmental regulations, comparative methodology, industrial activity, environmental management

\begin{abstract}
The approach of "pollute first, then clean up", has been understood to be hard both technologically and economically. Therefore, the necessity of adopting another strategy, which is anticipate-and-prevent, has risen and consequently the environmental impact assessment (EIA) has emerged as a tool. Screening is one of the earliest steps of every EIA process and it is characterized as the determination of whether or not an environmental assessment must be prepared for a particular project. The aim of this paper is to identify, analyse and compare the methodological models regulating the screening process of industrial activity in Argentina, a federal country without a national directive concerning this particular matter and where each of the 24 districts are autonomous in this matter. This research was followed through employing a comparative method, which was implemented based on secondary data analysis. Three guiding questions and three criteria were used to compare the 24 districts. Six different screening process models were described (both qualitative and quantitative). The six chosen models were integrated into three great groups. The group of districts that present "Preliminary study" + "Case by case" approaches prevail, while in second place comes the "Threshold" + "Case by case" approaches. Finally, the more complete screening model, with specific legislation for EIA in industries and a quantitative environmental complexity index, turned out to be the least applied in Argentina.
\end{abstract}

Palabras clave: legislación ambiental, método comparativo, actividad industrial, gestión ambiental

\section{RESUMEN}

El enfoque de "contaminar, luego limpiar", se considerada desde hace años inapropiado tanto en términos tecnológicos y económicos; así, la necesidad de adoptar otra estrategia, como "anticipar y prevenir" ha tomado mayor importancia y para ello surge como herramienta la evaluación de impacto ambiental (EIA). El screening es uno de los pasos iniciales de la EIA y es un proceso para determinar si un proyecto en particular debe presentar un estudio ambiental. El objetivo de este artículo es identificar, analizar y comparar los modelos metodológicos que regulan el proceso de revisión inicial para la actividad industrial en Argentina, un país federal sin una directiva nacional al respecto y donde cada uno de los 24 distritos son autónomos en este sentido. Se utilizó el método 
comparativo, implementado con base en datos secundarios. Se utilizaron tres preguntas guía y tres criterios para comparar los 24 distritos. Se distinguieron seis modelos de screening (tanto cualitativos como cuantitativos), los cuales se integraron finalmente en tres grandes grupos. El grupo que comprende "Estudio preliminar" + "Análisis caso por caso" es el que prevalece, siguiéndole el de "Umbrales" + "Análisis caso por caso". Finalmente, el modelo de screening más completo, con legislación específica para industrias y un índice cuantitativo de complejidad ambiental, resulta ser el menos aplicado en Argentina.

\section{INTRODUCTION}

Business and industry, including transnational corporations, play a crucial role within the social and economic development of a country (UN 1992). Even though industrial growth has favoured economic and spatial expansion in cities for over two centuries, industrial activities may be the culprit of some of the causes of environmental pollution today (Sosa et al. 2013).

In contrast to developed economies, industrial wastewater discharges in third world and transitional economies, where pollution control policies have not been implemented as vigorously, if not at all, do remain a concern (Earnhart 2013). In order to mitigate the negative impact caused by human activities, instruments obliging countries to adjust their policies and legislations are brought to table in different ways (international meetings, EU directives, UN directives, etc.). The approach of "pollute first, then clean up", is understood to be hard both technologically and economically (Rezaei-Moghaddam and Karami 2008). Therefore, the necessity of adopting another strategy, which is anticipate-and-prevent, has risen (Elvan 2018). In 1970 the United States of America adopted the National Environmental Policy Act (NEPA), which in Section 102 in Title I of the Act requires federal agencies to incorporate environmental consideration into their planning and decision-making by employing a systematic interdisciplinary approach (USEPA 1969).

Environmental Impact Assessment (EIA) study has become inevitable for projects and activities where natural resources will be used and negative effects on the environment are to be expected. It is the single and most decisive document that aims to achieving sustainable healthy environmental conditions through the "anticipate-and-prevent" strategy (Elvan 2018). EIA is a systematic process used to make decisions that takes into account the environmental impact assessment of human activities on the environment. The process helps to include environmental factors into the project proposal. EIA involves an assessment of the potential impacts of the project on the ecosystem (Reddy Maredy 2017).

Comparative analysis of countries' statutes and regulations offer immediate recourses for policy makers (Suwanteep et al. 2016). Comparative case studies of national EIA systems are widespread in literature (e.g. Glasson and Salvador 2000, Ahmad and Wood 2002, Kolhoff et al. 2013, Al-Azri et al. 2014, Gałaś et al. 2015). National case studies are also quite common for both developed and developing countries (e.g. Fowler and Dias De Aguiar 1993, Nadeem and Hameed 2008, Haydar and Pediaditi 2010); in this second group most of the publications are related to Southeast Asia, Eastern Europe and, to a lesser extent, Latin America (Ahmad and Wood 2002). These authors review and compare the performance of environmental impact assessment using the following criteria: legislative and administrative procedures for EIA; aspects of EIA such as screening, scoping, EIA report review, mitigation, etc.; and the decided measures undertaken to improve the effectiveness of EIA systems. However, more studies are needed to compare developing and developed countries, particularly subnational EIA systems, since they are eligible for the majority of implementations. There are very few studies that include a subnational focus, which is ironic considering that most EIAs are implemented by sub-national authorities (Loomis and Dziedzic 2018). This is the case in federal countries like Argentina.

EIA consists of different steps and stages. Screening is one of the first steps in every EIA process, and it is characterized by the determination as to whether or not an environmental assessment must be prepared for a particular project (Christensen and Kørnøv 2011). The screening decision must be recorded and made available to the public (EC 2001). The competent authority (CA) makes a decision on whether EIA is required. This may occur when the CA receives notification of the intention to present a development consent application, or the developer 
may make an application for a screening opinion. Should the CA screening opinion be positive, and EIA be a requirement, there would be implications for the project timeline that would include the necessary time required for technical studies, environmental statement (ES) preparation, and other requirements. There might possible be cost implications, with EIA commonly needing a greater, vaster reporting effort in the ES than for a non-EIA planning application (Melvill 2017).

The screening process can be based on two broad approaches: an inclusion/exclusion list of projects (with or without threshold limits) and case-by-case screening (Christensen and Kørnøv 2011). Pinho et al. (2010), based on the European Directive 97/11/EC differentiated four types of screening approaches: a. Preliminary study or initial environmental evaluation: The need for an EIA is taken into consideration by way of an early assessment process covering all types of projects in all circumstances. b. Case-by-case: The need for EIA is individually considered; it usually appears together with and as a complement to another screening method. c. List of projects: The need for EIA is based on lists of projects organized within different categories and types of projects. Positive lists specify the projects which require EIA, whereas negative lists present the exemptions. d. Thresholds: The need for EIA is based on specific measures and limits in accordance with a predefined criterion.

Even though the above definition conveys the objectiveness of the screening process in a simple and straight forward manner, the process of determining the same can become rather complicated in a developing country (Rajaram and Das 2011).

Argentina is a developing country in Latin America with a federal organization, which consists of 23 provinces and a Federal District (the autonomous city of Buenos Aires, CABA), located in the southern cone of South America, with an area of $2780400 \mathrm{~km}^{2}$ (Fig. 1). It is the second biggest country within South America. The distance from north to south is $3779 \mathrm{~km}$, and from east to west, is about $1384 \mathrm{~km}$. There are more than 2100 local councils and 43.85 million inhabitants.

Throughout history, Argentina has always been recognized as a country with important growth, regarding agricultural and livestock activities. In the $50 \mathrm{~s}$ a process of industrialization began in the country and as a result, industrial activities at this time became the main engine of economic development (CEPAL 1993).

Argentina's economy is basically divided into three main productive sectors: agricultural, industrial

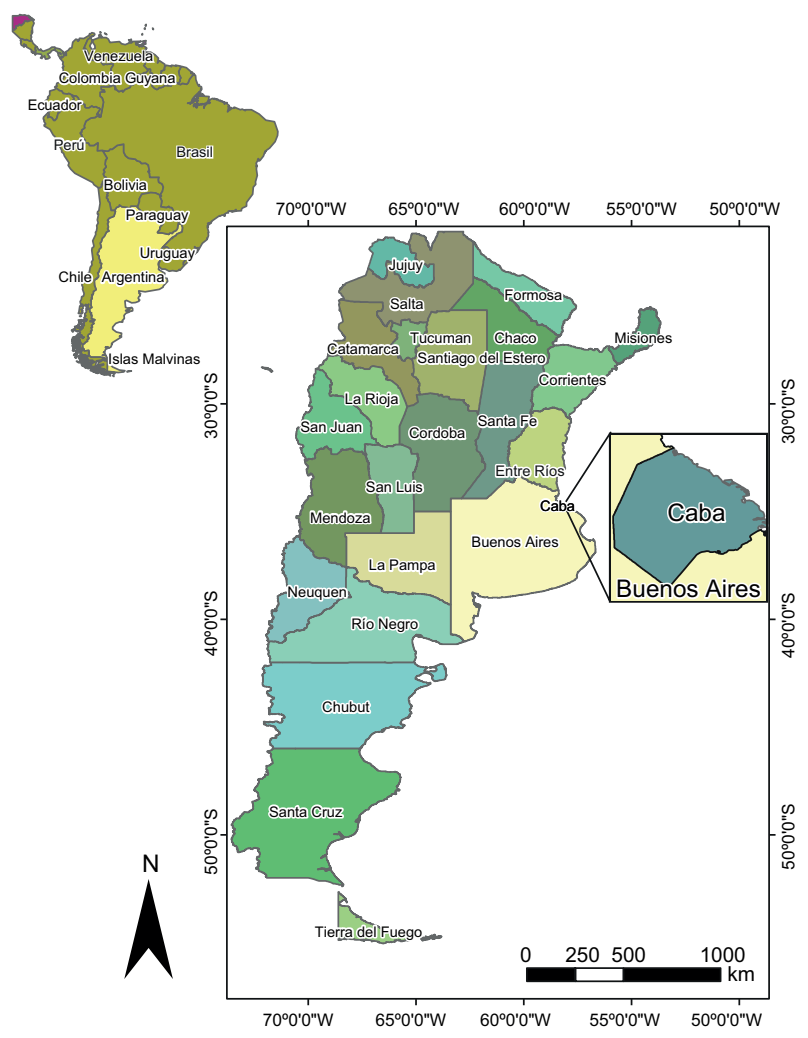

Fig. 1. Study area

and mining (Zappino 2014). According to the World Bank, in 2017 the manufacturing industry accounted for $22 \%$ of the country's Gross Domestic Product (GDP).

\section{Aim and research questions}

The three guiding questions for this research are:

1. Which type of environmental impact assessment legislation do the Federal District and every province have?

2. Is it possible to identify similarities and differences in the industrial EIA screening process in the Federal District and the 23 provinces?

An integrated subnational research about this subject does not actually exist in Argentina, unlike, for example, as it would in the European Union, where the EIA Directive outlines a common screening approach that is adopted by member states. It could be useful to systematize the screening process so as to facilitate its optimization and the analysis of the scoping process at a subnational level.

3. Are the criteria used in determining impact significance in the screening process objective (predetermined) or subjective (judgmental)? 
Some authors argue that there are always some objective measurable elements associated to the concept of significance in EIA, while others emphasize the intrinsic subjective nature of all environmental components and therefore reject any attempt to define objective measures. These differences give forth to difficulties in determining coherent forms of decision-making in screening (Pinho et al. 2010).

In accordance with these questions, the aim of this article is to compare and analyse at a subnational scale the industrial EIA screening process in Argentina.

At this present time, there is no existent normative systematisation in the country (in public access websites or whereabouts) that integrates the laws which regulate the EIA process for a new industry to establish itself in whichever province. Access to information in this regard, is very complex to analyse at a national dimension, due to the fact that in some provinces access is very simple and in others quite difficult.

\section{The Argentinian environmental legal framework}

Environmental governance in Argentina is multilayered and works within federal, provincial and municipal levels (WBG 2016).

It was not until the Rio Summit in 1992 that environmental legislation began to gain strength. A direct consequence of the Rio Summit in Argentina was the inclusion of environmental topics in the National Constitution, which was then amended in 1994.

- Article 41 establishes the right to 'a healthy, balanced environment suitable for human development and where productive activities meet present needs without compromising those of future generations'. This article recognizes the federal nature of the environmental legislation. 'The Nation shall regulate the minimum protection standards and the provinces where it be necessary to reinforce them, without altering their local jurisdictions'. It states that it is the duty of the national state to dictate the 'minimum budget laws' of environmental protection and the duty of the provinces to comply with them.

- Despite the fact that this article does not explicitly mention EIA as a management instrument, it offers three fundamental principles for an effective environmental protection. The principles are: access to environmental education, access to environmental information and access to justice.

In 2002 the Argentinian National State sanctioned the Environmental General Law (LGA) which established the minimum budgets needed to achieve a sustainable management of environment, preservation and protection of biological diversity and implementation of sustainable development (Article $\mathrm{N}^{\mathrm{N}}$ 1). The Argentina National State, in the Environmental General Law No 25675 (LGA), dictates only general guidelines about how the EIA process should be carried out. EIAs in Argentina have widely been applied as procedural permissive tools that allow major projects to move forward quickly, rather than tools to guide project design through a careful impact assessment and stakeholder buy-in (WBG 2016).

The articles that specifically deal with the topics analyzed in this paper regarding the screening process of environmental impact assessment in this law are:

- Article 8. -recognizing the environmental impact assessment as one of the most important instruments of environmental management and policy.

- Article 11.-indicating that any project or activity which, within the national territory, is likely to degrade the environment, any of its components, or affect life quality in a significant manner, shall be subject to an environmental impact assessment procedure, prior to their development or establishment.

This law does not specify the EIA administrative procedure in general or the screening procedure specifically.

\section{MATERIALS AND METHODS}

This research was carried out using a comparative method, which was implemented using secondary data analysis. This method consists of a systematic case-based comparison drawn up for empirical generalization and hypothesis verification purposes or through guiding questions (as is the case of this paper). This approach has been used in a vast number of papers and it is recommended when necessary to identify similarities and differences in various analysis units (AU) (Makón 2004, Pérez Liñán 2008, Van Hoecke 2015).

In this paper, the comparative method was implemented in four steps:

1. Identification of the territorial units to be compared.

2. Data source identification.

3. Identification and selection of comparison criteria. 
4. Application of selected criteria to each AU, systematization of the results and identification of common models (screening process).

For the first step, due to Argentina being a federal country, 24 AU were chosen, specifically the Federal District (City of Buenos Aires, CABA) and the 23 Argentinian provinces.

Step 2 was very relevant to this article. The absence of a centralized and systematized information flow led us to carry out an almost "archaeological reconstruction" of the screening procedure in each AU. The screening procedure in question consists of a process that took almost 30 years to consolidate. The $24 \mathrm{AU}$ governments websites were consulted to identify the CA (e.g. Secretariat/Ministry of Environment), as well as those responsible for the specific administration of the industrial sector (e.g. Ministry of Production). Once both CAs was identified, information on the EIA screening procedure for new industries was collected on all the agencies' websites responsible for environmental management and those responsible for administering the industrial sector. In order to fill some gaps, both the Scientific and Technological Promotion Ministry website and the
Justice and Human Rights Ministry legal database were consulted.

After going over the information and literature found on EIA, it was decided to base Step 3 on Ahmad and Wood (2002) and the Council Directive 97/11/EC 1997 (Pinho et al. 2010). Three screening evaluation criteria were selected for the analysis and comparison: 1) "Legal provisions for EIA". 2) "Specified Screening Categories". 3) "Systematic Screening Approach".

Finally, in step 4 the results were systematized and synthesized in an "Overall Screening Pattern" and also on a flow chart, which gathers criteria results analyzed in each AU and allows for a clear understanding of the screening process in each one of them. This last pattern could be useful for a screening process comparison of Argentina with other countries.

\section{RESULTS}

\section{Criterion 1 "Legal provisions for EIA"}

This criterion explains which type of legislation covers the environmental impact assessment; it allows for the identification of two different models (Fig. 2a):

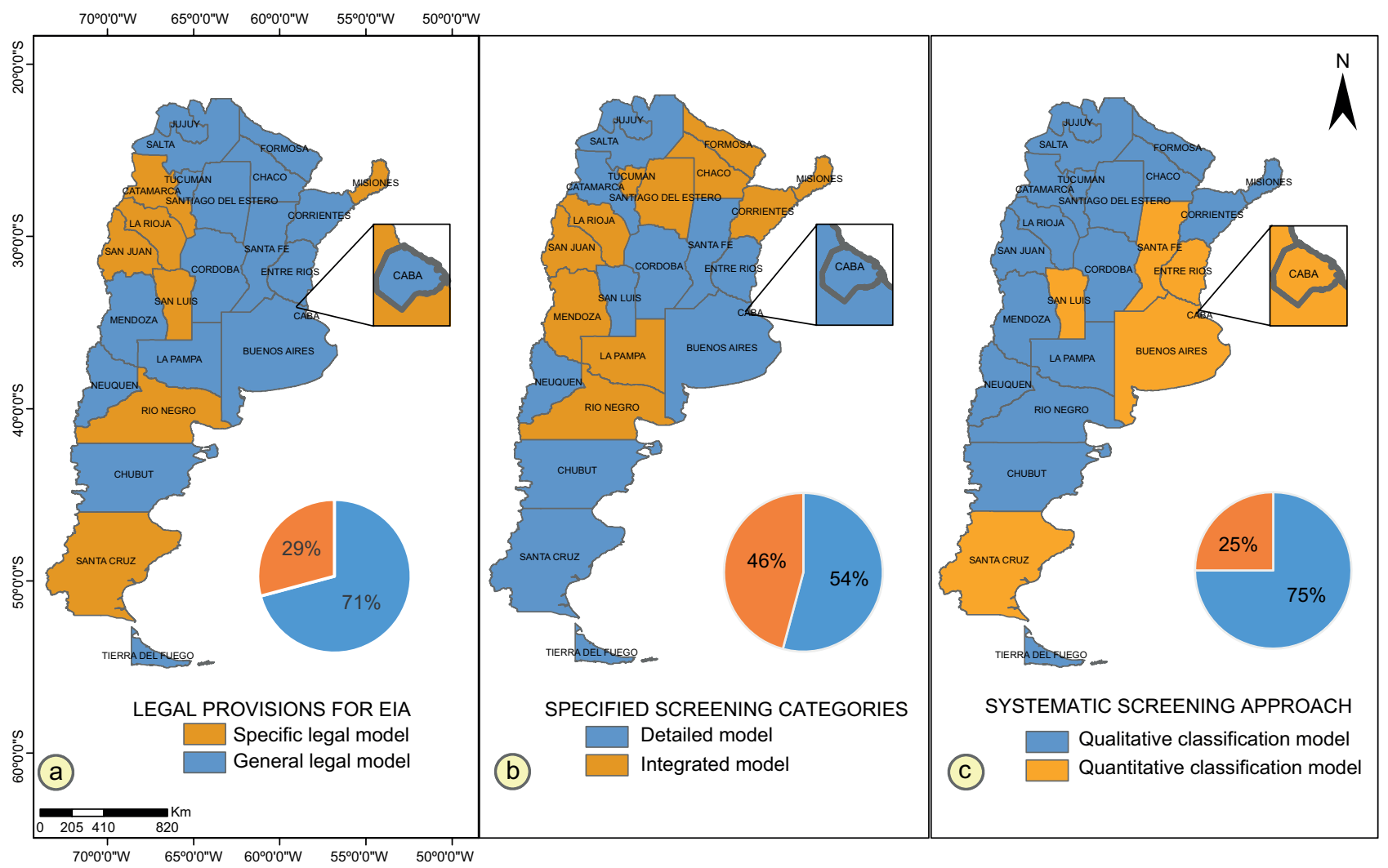

Fig. 2. Screening process models 
1. Specific legal model: it includes all the AU where a specific law that governs the EIA requirements and procedures exist. For example, in the San Juan province, Law $\mathrm{N}^{\circ} 6571$ of Environmental Impact Assessment describes in detail the EIA screening process, including the general guidelines for the preparation of the notice of project.

2. General legal model: it corresponds to all AU where general laws regarding environment already include the EIA process. For example, in the La Pampa province, Law N ${ }^{\circ} 1914$ establishes the provincial environmental policy and the environmental management tools, among which it mentions the EIA but without going into detail about the screening process.

Most of the studied AU (71\%) presents a general legal model.

\section{Criterion 2. "Specified Screening Categories"}

From this second criterion two models were identified.

1. Detailed model: it has been named "detailed model" because the legislation lists specifically which industrial fields must present an EIA ("positive list of projects"). For example, the Chubut province in Decree $\mathrm{N}^{\circ} 185$ establishes six industrial fields (chemical, oil, paper, iron foundries, non-ferrous metals production and industrial processes that contain asbestos).

2. Integrated model: this model is applied in those AU in which a "positive list" of industrial fields does not exist; only the general term 'industries' is included in a list with other activities that are conditionally subject to the presentation of an EIA.

For example, the Chaco province in its Decree $\mathrm{N}^{\circ} 1726$ only mentions generically the establishment of "industries and industrial parks" among other activities.

The detailed model has been adopted by $54 \%$ of the AU, including those which are more industrialized (Fig. 2b)

\section{Criterion 3. "Systematic Screening Approach"}

This criterion is of the most relevant importance because it is the one that defines the magnitude and significance of the more likely related environmental impact. Industries must submit the initial documentation or notice of intention to the CA that must include the basic information to be evaluated by way of one of the two models that have been identified (Fig. 2c):
1) Quantitative model: The AU legislation establishes an index called "environmental complexity level" (NCA, Table I), taking into consideration the information included in the notice of intention. The NCA defines three industrial categories (first, second and third category), and for each one there are different EIA requirements (also defining the environmental study requirements, if a public audience is mandatory, etc.). This model corresponds to "Threshold" + "Case by Case" approaches (Council Directive 97/11/EC).

The NCA is calculated by a linear equation that sums up five different variables:

- Activity classification: it is the industrial field (it can be classified according to the field international classification, in some cases).

- Effluents and waste quality: it includes the liquid effluents and gases released by the industry as well as solid and semi-solid waste.

- Risks: potential risks that an activity can present, such as fire, explosion, chemical, acoustic and by pressure devices which may affect the population or the surrounding environment.

- Dimensions: Project dimension, taking into consideration the number of employees, power installation and the surfaces covered.

- Location: Company location, taking into account the zone and the amenities infrastructure that it possesses.

For example, in the case of Buenos Aires province the range of values for each variable is:

- Activity classification (Ru): between 1 and 10

- Effluents and waste quality (ER): between 0 and 6

- Risks (Ri): between 1 and 5

- Dimensions (Di): between 0 and 4

- Location (Lo): between 0 and 4

Regarding industries that are classified as first category the CA grants the Environmental Aptitude Certificate (which allows the industry to operate) with just the information presented in the initial documentation or notice of intention; in the case of second and third categories the industries must present an EIA in accordance with the requirements established by each AU legislation; third category industries must also present a monitoring plan and may be subject to a public participation process.

Three AU use an "adjustment factor" that increments or diminishes the NCA obtained. The adjustment factor that diminishes the NCA is the implemen- 
TABLE I. ANALYSIS UNITS (AU) WITH A CLASSIFICATION PROCESS IN ITS LEGISLATION

\begin{tabular}{|c|c|c|c|c|}
\hline \multirow{2}{*}{$\frac{\mathrm{AU}}{\text { Buenos Aires }}$} & \multirow{2}{*}{$\begin{array}{l}\text { Equation } \\
\mathrm{NCA}=\mathrm{Ru}+\mathrm{ER}+\mathrm{Ri}+\mathrm{Di}+\mathrm{Lo}\end{array}$} & \multicolumn{3}{|c|}{ Categories/ Points } \\
\hline & & $1^{\mathrm{o}}$ & $2^{\circ}$ & $3^{\circ}$ \\
\hline & & $\leq 14$ & $15-25$ & $\geq 25$ \\
\hline \multirow[t]{2}{*}{ Entre Ríos } & \multirow[t]{2}{*}{$\mathrm{NCA}=\mathrm{Ru}+\mathrm{ER}+\mathrm{Ri}+\mathrm{Di}+\mathrm{Lo}$} & $1^{\mathrm{o}}$ & $2^{\circ}$ & $3^{\circ}$ \\
\hline & & $\leq 14$ & $15-25$ & $\geq 25$ \\
\hline \multirow[t]{2}{*}{ Santa Fe } & \multirow[t]{2}{*}{$\mathrm{NCA}=\mathrm{Ru}+\mathrm{ER}+\mathrm{Ri}+\mathrm{Di}+\mathrm{Lo}$} & $1^{\circ}$ & $2^{\circ}$ & $3^{\circ}$ \\
\hline & & $\leq 11$ & $12-25$ & $\geq 25$ \\
\hline \multirow[t]{2}{*}{ Santa Cruz } & \multirow[t]{2}{*}{$\mathrm{NCAi}=\mathrm{Ru}+\mathrm{ER}+\mathrm{Di}+\mathrm{Lo}$} & $1^{\mathrm{o}}$ & $2^{\circ}$ & $3^{\circ}$ \\
\hline & & $\leq 11$ & $12-25$ & $\geq 25$ \\
\hline \multirow[t]{2}{*}{ San Luis } & \multirow{2}{*}{$\begin{array}{l}\mathrm{NCAi}=\mathrm{Ru}+\mathrm{ER}+\mathrm{Ri}+\mathrm{Di}+\mathrm{Lo} \\
\mathrm{NCAf}=\mathrm{NCAi}+\mathrm{AjSP}-\mathrm{AjSGA}\end{array}$} & $1^{\mathrm{o}}$ & $2^{\circ}$ & $3^{\circ}$ \\
\hline & & $\leq 14$ & $15-25$ & $\geq 26$ \\
\hline \multirow[t]{3}{*}{ CABA } & $\mathrm{NO}$ & $\begin{array}{c}\text { Without relevant } \\
\text { effect }\end{array}$ & $\begin{array}{l}\text { Subject to } \\
\text { classification }\end{array}$ & $\begin{array}{c}\text { With relevant } \\
\text { effect }\end{array}$ \\
\hline & $\begin{array}{l}\text { YES (Subject to classification) } \\
\mathrm{NCA}=\sum \mathrm{A}+\sum \mathrm{B}\end{array}$ & $\begin{array}{l}\text { Without relevant } \\
\text { effect }\end{array}$ & \multicolumn{2}{|c|}{$\begin{array}{l}\text { With relevant } \\
\text { effect }\end{array}$} \\
\hline & & $<8.5$ & \multicolumn{2}{|c|}{$\geq 8.5$} \\
\hline
\end{tabular}

In order to clarify this table the original acronyms given in the legislation were modified. $\mathrm{Ru}=$ activity classification, ER $=$ effluents and waste quality, $\mathrm{Ri}=$ risks, $\mathrm{Di}=$ dimensions, $\mathrm{Lo}=$ location, $\mathrm{NCA}=$ environmental complexity level, NCAi $=$ initial environmental complexity level, $\mathrm{NCAf}=$ final environmental complexity level, AjSGA = adjustment factor for certified environmental management system, AjSP = adjustment factor for hazardous substances, AU = analysis units, $\mathrm{CABA}=$ autonomous city of Buenos Aires.

tation of an "Environmental Management and Safety System or an Integrated Management System". This particular system can be designed in accordance to ISO 9001 or ISO 14001, for example; the adjustment factor that increments the NCA refers to the handling of rather risky substances in specific quantities.

2) Qualitative model: General guidelines and requirements, that all activities must comply with, are put forward for the EIA presentation; the specific details of the environmental study are defined by the CA for each particular case. This model corresponds to "Case by Case" (Council Directive 97/11/EC) + "Preliminary study or initial environmental evaluation" approaches (Council Directive 97/11/EC, Pinho et al. 2010).

The vast majority of AU $(75 \%)$ has chosen the qualitative model (Fig. 2c).

\section{Overall screening model}

Lastly, using the information obtained from the previous model definitions, three management models of the EIA process in industry were identified (Table II).
1. Complete model: this model is characterized by specific EIA legislation, a detailed model of specified screening categories and a quantitative systematic screening approach.

2. Intermediate model: this model is characterized by any combinations that do not meet with the complete model nor the simplified model.

3. Simplified model: this model is characterized by a general legal EIA provision, an integrated model of specified screening categories and a qualitative systematic screening approach.

The least represented in this model are the complete $(13 \%)$ and the simplified models $(17 \%)$. Most AU (70 \%) present an intermediate model (Fig. 3). The first AU to adopt a complete model was CABA, before the LGA sanctions and after the national constitutional amendment. The other three AU that have adopted this model did so after 2002 (after LGA).

In figure 4 a flow chart of the administrative procedure of the screening process in Argentina is shown. This figure was elaborated with the 
TABLE II. CRITERIA AND MODELS

\begin{tabular}{|c|c|c|c|c|c|c|}
\hline \multirow[t]{2}{*}{$\mathrm{AU}$} & \multicolumn{3}{|c|}{ Legal provisions EIA } & \multirow{2}{*}{$\begin{array}{l}\text { Specified screening } \\
\text { categories }\end{array}$} & \multicolumn{2}{|c|}{ Systematic screening Overall screening } \\
\hline & Specific & General & Year & & approach & model \\
\hline CABA & Law 123 & & 1998 & DM & Quantitative. & $\mathrm{CM}$ \\
\hline Buenos Aires & & Law 11723 & 1995 & DM & Quantitative & InM \\
\hline Catamarca & Legal Provision SA 74 & & 2010 & DM & Qualitative & InM \\
\hline Chaco & & Law 3964 & 1994 & IM & Qualitative & $\mathrm{SM}$ \\
\hline Chubut & & Law 5439 & 2005 & DM & Qualitative & InM \\
\hline Córdoba & & Law 7343 & 1985 & DM & Qualitative & InM \\
\hline Corrientes & & Law 5067 & 1996 & $\mathrm{IM}$ & Qualitative & SM \\
\hline Entre Ríos & & Decree 4977 & 2009 & DM & Quantitative & InM \\
\hline Formosa & & Law 1060 & 1993 & $\mathrm{IM}$ & Qualitative & SM \\
\hline Jujuy & & Law 5063 & 1998 & $\mathrm{DM}$ & Qualitative & InM \\
\hline La Pampa & & Law 1914 & 2000 & IM & Qualitative & SM \\
\hline La Rioja & & Law 7371 & 2002 & $\mathrm{IM}$ & Qualitative & SM \\
\hline Mendoza & & Law 5961 & 2002 & IM & Qualitative & SM \\
\hline Misiones & Law 3079 & & 1993 & IM & Qualitative & InM \\
\hline Neuquén & & Law 1875 & 1990 & DM & Qualitative & InM \\
\hline Río Negro & Law 3266 & & 1998 & $\mathrm{IM}$ & Qualitative & InM \\
\hline Salta & & Law 7070 & 2000 & DM & Qualitative & InM \\
\hline San Juan & Law 6571 & & 1995 & IM & Qualitative & InM \\
\hline San Luis & Law XI-876 & & 2013 & DM & Quantitative. & $\mathrm{CM}$ \\
\hline Santa Cruz & Law 2658 & & 2003 & DM & Quantitative. & $\mathrm{CM}$ \\
\hline Santa Fe & & Law 11717 & 1999 & DM & Quantitative. & InM \\
\hline Santiago del Estero & & Law 6321 & 1996 & IM & Qualitative & $\mathrm{SM}$ \\
\hline Tierra del Fuego & & Law 55 & 1992 & DM & Qualitative & InM \\
\hline Tucumán & & Law 6253 & 1991 & $\mathrm{IM}$ & Qualitative & SM \\
\hline
\end{tabular}

$\mathrm{AU}=$ analysis units, $\mathrm{EIA}=$ environmental impact assessment, $\mathrm{CABA}=$ autonomous city of Buenos Aires, SA = environmental undersecretary, $\mathrm{DM}=$ detailed model, $\mathrm{IM}=$ integrated model, $\mathrm{CM}=$ complete model, $\mathrm{InM}=$ intermediate model, $\mathrm{SM}=$ simplified model.

comparative analysis of the 24 political-administrative districts in Argentina.

\section{DISCUSSION}

Amongst the concerns raised in this paper, it comes to light that a unique management model of industrial EIA screening does not exist in Argentina, having already identified three models in the EIA screening process. It is important to highlight the shoddy, uncoordinated manner in which the legislation is handled in the different AU. This could be attributed to basically two factors: the first one is that Argentina is a federal country and there is no specific national EIA law that indicates general guidelines for the screening process. In second place, because of the lack of a national directive to guide provinces in the generation of their own legislation; the process has gone on for 28 years (1985 to 2013) so the social, economic and political situation was very different for every province at the moment of regulating the EIA process. This circumstance might have a certain influence on the scoping process, but that analysis is beyond the realm of this paper. It is also of interest to mention, as a hypothesis, the importance the constitutional amendment (1994) has had on the AU, since $50 \%$ of them sanctioned their environmental legislation between 1995 and 2002. It is also worth pointing out that three AU (12\%) enacted their EIA legislation before the Rio Conference (but with a general model). This shows how important it would have been for a country like Argentina, to count on a national directive that would have allowed unifying the criteria applied in the screening process. The screening process reconstruction made in this paper has allowed to verify that the process, in general, does not differ too much from what happens in the rest of the world (project preparation, notice of Project, CA intervention, screening methodology selection). The complexity that results in the main difference found is that this reconstruction does not exist as an integrated model in a national regulation. As happens in other countries, in some Argentinian provinces overlapping between the screening and scoping processes does occur. 


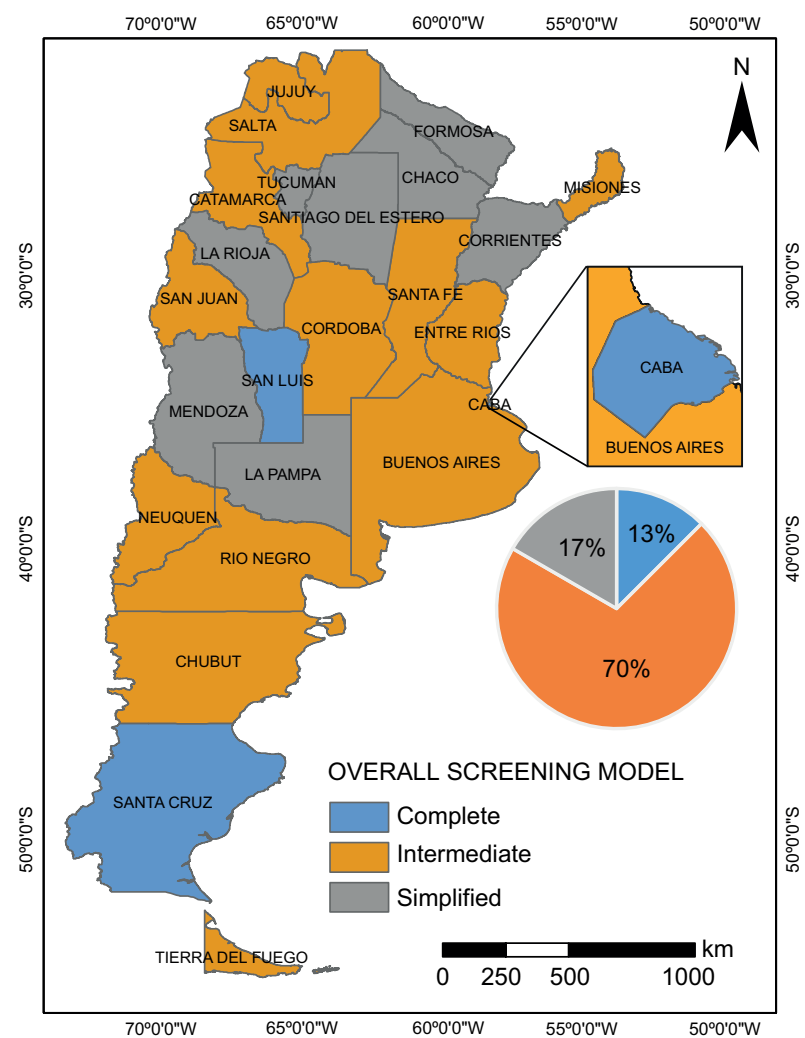

Fig. 3. Overall screening model

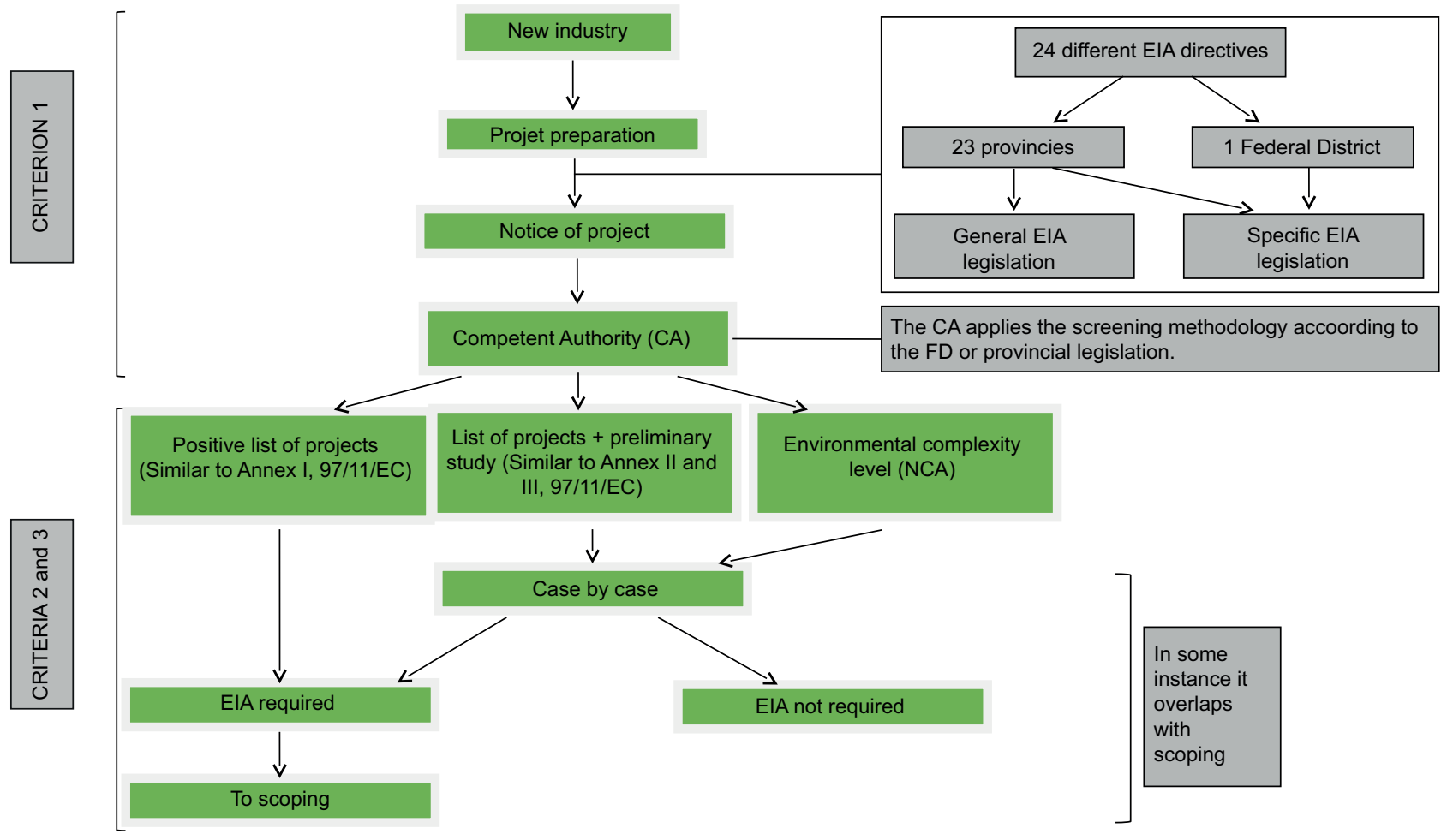

Fig. 4. Screening procedure and methodological synthesis

$\mathrm{EIA}=$ environmental impact assessment, $\mathrm{NCA}=$ environmental complexity level, $\mathrm{FD}=$ federal district 
Considering the "Overall Screening Model", one of the positive aspects of the complete model is the importance of having an exact environmental classification of industries in accordance with their complexity (objective criterion); accomplished by the calculation index (NCA) which is considered a relevant contribution in six of the $24 \mathrm{AU}$. This proffers a better adjustment to the requested requirements in the EIA process in accordance with their complexity. Taking into account the variables used in the systematic screening approach, all the AU recognize three principle groups of criteria: the first relating to the industrial field, location and dimensions. A positive aspect is that the location of the industry is taken into consideration in the determination of the NCA, and that whenever this location changes, a new categorization procedure must be initiated. This is a positive point since, obviously, the characteristics of the surroundings change as well as hazardous focal points that could be caused. The second one is related to effluents; and the third to possible health risks to neighbours and workers.

Although it is considered that these three groups are suffice to represent the environmental complexity of an industry properly, it is important to mention that liquid effluents, gaseous emissions and solid waste, are contemplated in the same term when calculating the NCA. This could lead to a lack of specification in these particular issues. Taking into consideration the adjustment factors in the calculation of the environmental complexity level can be seen as a particularly positive aspect. This is due to the fact that it is possible to separately identify hazardous waste from innocuous types; and it also positively values the adherence of industry to international certification of environmental management systems.

\section{CONCLUSIONS}

The comparative method has proven to be efficient enough to carry out the reconstruction of the information referred to, in the screening process execution in Argentina, allowing the identification of three screening models that synthesize the way in which each AU carry forward this process; the greatest difficulty encountered in the application of this method has been information access. On the other hand, Ahmad and Wood (2002) selected criteria, was appropriate to be applied in a federal country such as Argentina, despite the elapsed time. Regarding, the "Systematic Screening Categories" and the "Systematic Screening Approach" it has been verified that there is a good correlation between the identified models in the AU with the 97/11/EC Annex I, II and III. In Argentina the "Preliminary study or initial environmental evaluation approach" + "Case by Case" approaches prevail in such a way as to be noticed, while in second place comes the "Threshold" + "Case by Case" approaches.

From the analyzed results it comes up that the "complete screening model" should be taken as a national guide, since it includes a discrimination of the different industrial activities and a quantitative (objective) model to determine the scope of the information to be presented. Despite being the model that provides more detail, it is the lesser applied since only a mere $13 \%$ of the provinces present it.

Finally, a recommendation that arises from this paper is to develop technical EIA guidelines to cover legislation, thereby creating a more uniform standard EIA screening process among the AU. These guidelines could be designed by the National Government, with the collaboration of the provincial authorities, particularly in the analysis and evaluation of the lessons already learnt. It is important to mention that at this moment a propitious interjurisdictional area integrated by the $24 \mathrm{AU}$ (COFEMA, Environmental Federal Council) already exists, so this task could be brought about.

\section{REFERENCES}

Ahmad B. and Wood C. (2002). A comparative evaluation of the EIA systems in Egypt, Turkey and Tunisia. Environ. Impact Assess. Rev. 22 (3), 213-34. DOI: $10.1016 / \mathrm{S} 0195-9255(02) 00004-5$

Al-Azri N.S., Al-Busaidi R.O., Sulaiman H. and Al-Azri A.R. (2014). Comparative evaluation of EIA systems in the Gulf Cooperation Council States. Impact Assess. Proj. A. 32 (2), 136-149.

DOI: $10.1080 / 14615517.2014 .893620$

CEPAL (1993). La Industria Argentina. Un proceso de reestructuración desarticulada. Buenos Aires. Comisión Económica para América Latina y el Caribe. Work document, Buenos Aires, Argentina, 41 pp.

Christensen P. and Kørnøv L. (2011). EIA screening and nature protection in Denmark. J. Environ. Manage. 92 (4), 1097-1103. DOI: 10.1016/j.jenvman.2010.11.010

EC (1997). Council Directive 97/11/EC on the assessment of the effects of certain public and private projects on the environment. European Council. Directive. Luxembourg, Brussels, $11 \mathrm{pp}$.

Earnhart D. (2013). Water Pollution from Industries Sources. In: Encyclopedia of energy, natural resources 
and environmental economics. (J.F. Shogren, Ed.), Elsevier, Oxford, UK, pp. 114-120.

DOI: 10.1016/B978-0-12-375067-9.00091-7

EC (2001). Guidance on EIA, screening. European Commission. Guide, Luxembourg, Brussels, 83 pp.

Elvan O. S. (2018). Analysis of environmental impact assessment practices and legislation in Turkey. Environ. Sci. Policy. 84, 1-16.

DOI: $10.1016 /$ j.envsci.2018.02.008

Fowler H.G. and Dias De Aguiar A.M. (1993). Environmental impact assessment in Brazil. Environ. Impact Assess. 13 (3), 169-176.

DOI: 10.1016/0195-9255(93)90030-F

Gałaś S., Gałaś A., Zeleňáková M., Zvijáková L., Fialová J. and Kubíčková H. (2015). Environmental Impact Assessment in the Visegrad Group countries. Environ. Impact Assess. 55, 11-20.

DOI: 10.1016/j.eiar.2015.06.006

Glasson J. and Salvador N.N.B. (2000). EIA in Brazil: A procedures-practice gap. A comparative study with reference to the European Union, and especially the UK. Environ. Impact Assess. 20 (2), 191-225.

DOI: 10.1016/S0195-9255(99)00043-8

Haydar F. and Pediaditi K. (2010). Evaluation of the environmental impact assessment system in Syria. Environ. Impact Assess. 30 (6), 363-370.

DOI: 10.1016/j.eiar.2009.11.003

Kolhoff A.J., Driessen P.P.J. and Runhaar H.A.C. (2013). An analysis framework for characterizing and explaining development of EIA legislation in developing countries-Illustrated for Georgia, Ghana and Yemen. Environ. Impact Assess. 38, 1-15.

DOI: 10.1016/j.eiar.2012.04.004

Loomis J.J. and Dziedzic M. (2018). Evaluating EIA systems' effectiveness: A state of the art. Environ. Impact Assess. 68, 29-37. DOI: 10.1016/j.eiar.2017.10.005

Makón A. (2004). Métodos comparativos en ciencias sociales : algunas reflexiones en relación a sus ventajas y limitaciones. Proceedings. VI Jornadas de Sociología, Facultad de Ciencias Sociales. Universidad de Buenos Aires, Buenos Aires. 20 al 23 de octubre, 2004. Pp. 1-19.

Melvill G. (2017). When should you screen for EIA? [online]. https://thelandmarkpractice.com/screeningfor-eia/ 13/06/2018.

Nadeem O. and Hameed R. (2008). Evaluation of environmental impact assessment system in Pakistan. Environ. Impact Assess. 28 (8), 562-571.

DOI: 10.1016/j.eiar.2008.02.003
Pérez-Liñán A. (2008). El método comparativo: fundamentos y desarrollos recientes. Revista Latinoamericana de Política Comparada 3, 125-148.

Pinho P., McCallum S. and Cruz S.S. (2010). A critical appraisal of EIA screening practice in EU Member in states. Impact Assess. Proj. Apprais. 28 (2), 91-107. DOI: $10.3152 / 146155110 X 498799$

Rajaram T. and Das A. (2011). Screening for EIA in India: Enhancing effectiveness through ecological carrying capacity approach. J. Environ. Manage. 92 (1), 140148. DOI: $10.1016 /$ j.jenvman.2010.08.024

Reddy-Maredy A. (2017). Conceptual facets of EIA. In: Environmental Impact Assessment, Theory and Practice. (P. Jardim, Ed.). Elsevier, Oxford, UK, pp. 1-29. DOI: 10.1016/B978-0-12-811139-0.00001-3

Rezaei-Moghaddam K. and Karami E. (2008). Developing a green agricultural extension theory. International Journal of Sustainable Development and Planning 3 (3), 242-256. DOI: 10.2495/SDP-V3-N3-242-256

Sosa B.S., Guerrero E.M. and Noriega R.B. (2013). Industria, emisiones gaseosas y gestión ambiental urbana. Gestión y Ambiente 16 (1), 61-70.

Suwanteep K., Murayama T. and Nishikizawa S. (2016). Environmental impact assessment system in Thailand and its comparison with those in China and Japan. Environ. Impact Assess. 58, 12-24.

DOI: 10.1016/j.eiar.2016.02.001

UN (1992). Agenda 21. The UN conference on environment and development. United Nations Division for Sustainable Development. Agenda. Rio de Janeiro, Brazil, 351pp.

USEPA (1969). The national environmental policy act of 1969, as amended. United States Environmental Protection Agency. Washington, D.C., USA, 7 pp.

Van Hoecke M. (2015). Methodology of comparative legal research. Law and Method 12, 1-35. DOI: $10.5553 / \mathrm{REM} / .000010$

WBG (2016). Argentina-country environmental analysis. The World Bank Group. Technical Report. Washington, D.C., USA, 92pp.

WBG (2019). World development indicators. The World Bank Group [online]. http://wdi.worldbank.org/ table/4.2 17/04/2019.

Zappino J. S. (2014). Las políticas públicas como herramienta para el desarrollo industrial argentino 20032011. Proceedings. XIX Congreso Internacional del CLAD sobre la Reforma del Estado y de la Administración Pública. Quito, Ecuador. 11 al 14 de noviembre, 2014. 1-27. 